\title{
When Are States Liable Towards Individuals for Serious Violations of Humanitarian Law? The Marković Case
}

\author{
Micaela Frulli*
}

\begin{abstract}
In February 2002, the Italian Supreme Court rejected an application filed by Federal Republic of Yugoslavia (FRY) citizens requesting compensation for the death or injuries suffered by their relatives following the NATO bombing of Radio Televizije Srbiijre (RTS) in 1999. The Supreme Court expanded the application of the 'political question' doctrine beyond the limits so far accepted and, certainly, beyond the limits that should be respected in order to ensure compliance with international law. The obligation to pay damages caused to individuals as a result of breaches of humanitarian law could derive from Article 3 of the 1907 Hague Convention IV and Article 91 of the 1977 First Additional Protocol. However, textual analysis of these two provisions does not dispel their ambiguity. Subsequent state practice shows that these rules have been interpreted as an interstate obligation and not as conferring a right on individuals. The author suggests a new interpretation intended to reconcile state practice with the right of individuals to seek and obtain compensation. Article 3 and Article 91 could be interpreted as granting individuals a right to compensation in all those cases where the payment of damages is not provided through interstate mechanisms.
\end{abstract}

\section{Introduction}

The NATO bombing campaign conducted in 1999 against the Federal Republic of Yugoslavia (FRY) gave rise to a number of cases before national and international tribunals. On 29 April 1999, the FRY instituted proceedings against Belgium and nine other states before the International Court of Justice (ICJ), after having expressly 
recognized its compulsory jurisdiction. The case is still pending. ${ }^{1}$ Some nationals of the FRY also lodged an application, in October 1999, with the European Court of Human Rights (ECHR) against Belgium and the other 16 countries that participated in the NATO bombing campaign. The ECHR held that there was no jurisdictional link between the victims of the act complained of and the respondent states; it therefore declared the application inadmissible. ${ }^{2}$

In addition, no proceedings were instituted before the International Tribunal for the Former Yugoslavia (ICTY). In May 2000 the Committee entrusted by the ICTY prosecutor with the task of reviewing 'Operation Allied Force' advised the prosecutor not to open an investigation into the NATO bombing campaign. Accordingly, the prosecutor decided not to commence an investigation. ${ }^{3}$

More recently, in February 2002, the Italian Supreme Court (Corte di cassazione) rejected a civil complaint filed by FRY citizens (Dusko Marković and others) requesting compensation for the death or injuries suffered by their relatives following a specific incident: the NATO bombing of Radio Televizije Srbiijre (RTS) on 23 April 1999. ${ }^{4}$ The complaint, filed with the Rome tribunal as a court of first instance, had been immediately brought before the Supreme Court for a preliminary ruling on admissibility (regolamento preventivo di giurisdizione). ${ }^{5}$ The Supreme Court held that Italian courts had no jurisdiction over the case.

So far no court, either national or international, has considered the merits of claims arising from the NATO bombing campaign of $1999 .^{6}$

1 The other nine states are: Canada, France, Germany, Italy, Netherlands, Portugal, UK, Spain and the US: the applications are available on the website of the ICJ, at www.icj-cij.org/icjwww/idecisions.htm

2 Application 52207/99, Banković and others v. Belgium and others, Decision delivered on 12 December 2001, available at http://hudoc.echr.coe.int/Hudoc1doc2/HEDEC/200112/52207_die.doc (visited April 2003). The other 16 States are Czech Republic, Denmark, France, Germany, Greece, Hungary, Iceland, Italy, Luxembourg, Netherlands, Norway, Poland, Portugal, Spain, Turkey, and UK.

3 For the Final Report of the Committee, see www.un.org/icty/pressreal/nato061300.htm (visited April 2003). The report has been severely criticized by some scholars: P. Benvenuti, 'The ICTY Prosecutor and the Review of the NATO Bombing Campaign against the Federal Republic of Yugoslavia' 12 European Journal of International Law (2001) 503-529; M. Bothe, 'The Protection of the Civilian Population and NATO Bombing on Yugoslavia: Comments on a Report to the Prosecutor of the ICTY', ibid., 531-535; W. J. Fenrick, 'Targeting and Proportionality during the NATO Bombing Campaign against Yugoslavia', ibid., 489-502.

4 Ordinanza della Corte di Cassazione, Sezioni Unite Civili, 8 Febbraio 2002. The court's order is reproduced in 85 Rivista di diritto internazionale (2002), with a note by N. Ronzitti, 'Azioni belliche e risarcimento del danno', at 682-690.

5 The application brought before the Rome Tribunal (Atto di citazione nei confronti della Presidenza del Consiglio dei Ministri, del Ministero della Difesa e del Comando delle Forze Alleate dell'Europa meridionale AFSOUTH, 31 Maggio 2000) and the request of a preliminary ruling on admissibility (Ricorso per regolamento preventivo di giurisdizione contro gli attori del procedimento civile instaurato il 31 Maggio 2000 di fronte al Tribunale civile di Roma, 16 Ottobre 2000) are reproduced in E. Sciso (ed.), L'intervento in Kosovo. Aspetti internazionalistici e interni (Milano: Giuffrè, 2001), 399-409.

6 Compensation claims arising from the NATO bombing campaign have been rejected by national courts of other countries as well. For instance, as to the Netherlands, see the judgment of the Hague Court of Appeal in Daniković v. the State of the Netherlands (23 November 2000), reprinted in E. Sciso (ed.), supra note 5, at 437 and the three other similar cases quoted (but not reprinted) therein: Stanojević, Tijsterman-Banicević and Dedović. 
The Italian Supreme Court's order - as well as the aforementioned decisions and reports, albeit from a different viewpoint - can be faulted in many respects, as will be shown in the following pages. It also offers an opportunity more generally to address the issue of states' liability to pay compensation to the victims of serious violations of humanitarian law.

\section{The Decision of the Italian Supreme Court in Marković}

The initial application filed with the Rome Tribunal alleged the violation of several provisions of the 1977 First Additional Protocol to the Geneva Conventions of 1949 relating to the Protection of Victims of International Armed Conflict (Protocol I). ${ }^{7}$ The claimants also invoked Article 91, Protocol I - which provides for states' liability to compensate in a case of breach of the Geneva Conventions or Protocol I - as a ground for requesting the payment of damages. ${ }^{8}$ Although the nationality of the planes that bombed RTS on 23 April 1999 was unknown, the liability of the Italian Government was invoked on account both of the participation in the NATO decision to select RTS as a specific target, and to use Italian military bases to conduct the bombing operation. ${ }^{9}$

In response to the claim, the Italian Government immediately filed a request with the Supreme Court for a preliminary ruling on admissibility, on the basis of lack of jurisdiction. The request was accepted and the court issued an order ruling that the Italian judiciary lacked jurisdiction over the case.

The Supreme Court briefly addressed, first, the question of which court was competent to pronounce on admissibility. It held that the admissibility of a case in which the respondent claims lack of jurisdiction is a preliminary question and not an issue relating to the merits; hence, pursuant to the Italian Code of Civil Procedure, the Supreme Court itself was competent to pronounce on the matter. ${ }^{10}$

7 The applicants referred to Articles 35, 48 and 51 of Protocol I. They also quoted Article 79, specifically protecting journalists who must be considered as civilians according to the definition contained in Article 50, para. 1 of Protocol I. See Atto di citazione, supra note 5, at paras 13 and 26.

8 See Atto di citazione, supra note 5, at para.31.

9 The applicants also invoked Article VIII, para. 5 of the 1951 London Agreement between the Parties to the North Atlantic Treaty Regarding the Status of Their Forces, which however could not be applied to the case at issue, see infra note 13.

10 The court's order reads: 'È questione di giurisdizione, la cui soluzione può essere chiesta alle sezioni unite con l'istanza di regolamento, anche quella su cui si deve statuire che ogni giudice difetta di giurisdizione', see Ordinanza, supra note 4, at para 1. To support their interpretation the judges have referred to their own case law, in particular to a Supreme Court order of 1978. However, they disregarded all the decisions the Supreme Court itself had rendered after 1978, that is all the cases in which it had ruled that this class of issue concerned the merits of a case and must therefore be addressed by the civil court with which the application had been filed (see, for instance: Cassazione, Sezioni Unite, 9 Novembre 1992, n. 12079 in Foro italiano, 1993, I, 2086; Cassazione, Sezioni Unite, 7 Gennaio 1993, n. 66, Foro italiano, Repertorio, 1993 (voce Giurisdizione civile), n. 143; Cassazione, Sezioni Unite, 22 Maggio 1995, n. 5605 in Archivio delle Massime civili della Corte di Cassazione (CED database); Cassazione, Sezioni Unite, 29 Settembre 1997, n. 9550 in CED database; Cassazione, Sezioni Unite, 22 Ottobre 1997, n. 10376 in CED database; Cassazione, Sezioni Unite, 30 Giugno 1999, n. 368 in CED database; 
The court proceeded to explain why Italian courts had no jurisdiction over the case. In a very concise ruling, the court held that the choice of means and methods of warfare falls among the 'acts of government', which are the manifestation and exercise of a political function; hence, by their very nature, they are non-justiciable. ${ }^{11}$ The court, in endeavouring to bolster its decision, also added that international rules regulating the conduct of hostilities and protecting the civilian population in case of attack $^{12}$ play their role only in inter-state relations. Specifically, Protocol I and the European Convention on Human Rights provide that international courts are the appropriate bodies to pronounce on the issue of state responsibility for violations of the provisions contained therein. Accordingly - so the court went on to say - the laws implementing these treaties in the Italian legal system do not confer on individuals the right to bring an action seeking reparation for injuries suffered as a result of violations of humanitarian law by the Italian state, nor do they provide for an individual ad hoc complaint procedure. In any case, such a provision would be in contradiction with the notion that the exercise of political functions cannot per se give rise to violations of individuals' rights or interests. ${ }^{13}$

\section{The 'Act of Government' or 'Political Act' Doctrine}

The court's reasoning behind the dismissal of the claim gives rise to a number of critical remarks. The main point on which the decision may be faulted is its reliance on

Cassazione, Sezioni Unite, 29 Novembre 1999, n. 832 in CED database). The latter interpretation is
indeed more consistent with the right to an effective judicial remedy, which, in the Italian system, may
be implemented through three different sets of proceedings: first instance, appeal, and, if need be,
judgment by the Court of Cassation, pronouncing on legal issues solely. It is therefore surprising that the
judges did not mention this consolidated jurisprudential trend and actually reversed it without any
explanation.

11 'La scelta di una modalità di conduzione delle ostilità rientra tra gli atti di Governo. Sono questi atti che costituiscono manifestazione di una funzione politica, della quale è nella Costituzione la previsione della sua attribuzione a un organo costituzionale: funzione che per sua natura è tale da non potersi configurare, in rapporto ad essa, una situazione di interesse protetto a che gli atti in cui si manifesta assumano o non assumano un determinato contenuto ( . . . . . Rispetto agli atti di questo tipo nessun giudice ha potere di sindacato circa il modo in cui la funzione è stata esercitata.', Ordinanza, supra note 4, at para. 2.

12 The Supreme Court referred to Articles 35, para. 2; 48; 49; 51; 52; and 57, Protocol I, and to Articles 2 and 15, para. 2, European Convention on Human Rights.

13 The Supreme Court rightly declined the possibility of applying Article VIII, para. 5 of the 1951 London Agreement, see supra note 9. This is an agreement between the parties to the North Atlantic Treaty regarding the status of their forces, and it obviously applies only to state parties. Article VIII, para. 5 reads: 'Claims (other than contractual claims and those to which paragraphs 6 or 7 of this Article apply) arising out of acts or omissions of members of a force or civilian component done in the performance of official duty, or out of any other act, omission or occurrence for which a force or civilian component is legally responsible, and causing damage in the territory of the receiving State to third parties, other than any of the Contracting Parties, shall be dealt with by the receiving State in accordance with the following provisions ( ... )' (emphasis added). As is obvious from the wording of this paragraph, third parties can bring a damages claim only for acts committed in the territory of the receiving state, which must be a state party to the London Agreement. 
the 'act of government' doctrine (teoria dell'atto di governo) as the main justification for holding the case non-justiciable.

The non-justiciability of 'political acts' or 'acts of government' is recognized in many legal systems, although with some differences in denomination and meaning. The doctrine was first propounded in France (actes de gouvernement) and later exported to the UK, under the 'royal prerogative' label, as well as to the US, where it is commonly referred to as the 'political question' doctrine. ${ }^{14}$ Through this mechanism of judicial restraint, courts occasionally refuse to consider claims that concern actions taken by the government. This deference is considered appropriate in circumstances where the exercise of governmental discretion is essential to protect constitutional or political interests. ${ }^{15}$

As far as Italy is concerned, case law shows that acts performed within the framework of international relations are to be considered as 'acts of government' or 'acts of a political nature' and are therefore non-justiciable. For instance, the government may not be summoned before the judiciary for concluding a treaty or for complying with a UN resolution. ${ }^{16}$

However, it would seem that it is the first time an Italian court has rejected a claim brought against the government relying on the 'political act' doctrine as far as 'acts of war' are concerned. As a partial precedent, one may refer to an important case where Italian courts dismissed a compensation claim filed against some Italian Resistance fighters (partigiani) for their bombing attack in Rome in 1944 (attentato di via Rasella). Also on that occasion courts resorted inter alia to the 'political question' doctrine to

14 See O. Ranelletti, 'Atti politici (o di governo)', $\mathrm{I}^{2}$ Novissimo Digesto Italiano, 1511-1515; P. Barile, 'Atto di governo (e atto politico)', IV Enciclopedia del diritto, 220-232. For a general overview, see E. Lauterpacht (ed.), Individual Rights and the State in Foreign Affairs: An International Compendium (New York: Praeger, 1977). With regard to the US, see T.M. Franck, Political Questions/Judicial Answers. Does the Rule of Law Apply to Foreign Affairs? (Princeton: Princeton University Press, 1992). For the application of the 'political question' doctrine in other countries, see also the articles in this symposium.

15 '... dalla enumerazione di tali atti si può, malgrado la diversità della loro natura dal punto di vista materiale, dedurre un concetto generale dell'atto di governo. E invero si può osservare che vi è un elemento comune e dominante che appare in ognuno di essi; si può notare cioè che la considerazione dell'interesse generale dello Stato nella sua unità diviene fondamentale e determinante per la volontà dell'organo che li pone in essere.' Ranelletti, supra note 14, at 1513.

16 Consiglio di Stato, IV, 11/5/1966, n. 344 (Accardo c. Ministero di Grazia e Giustizia), 91 Foro Italiano (1967), III, 118; Cassazione Sezioni Unite, 21 Marzo 1967, n. 631 (Lovati c. Ministero del tesoro), 51 Rivista di diritto internazionale (1968) at 122; 'gli atti compiuti dallo Stato nel regolamento delle relazioni internazionali', Cassazione Sezioni Unite 12 Luglio 1968, n. 2452, in 93 Foro italiano (1969), I, 479; or acts pertaining to the 'disciplina normativa delle relazioni tra Stati sovrani nel settore politico diplomatico', Cassazione Sezioni Unite, 14 Novembre 1974, n. 3068, 99 Foro italiano (1975), I, 1158. Italian courts also affirmed that decisions taken to comply with UN resolutions cannot be impugned before any tribunal: Tribunale di Roma, 19 Ottobre 1991 (Soc. Fincantieri e Soc.Otto Melara c. Min. Commercio con l'Estero ed altri), 115 Foro italiano (1991), I, 3230. Excerpts of the aforementioned documents are collected in P. Picone, B. Conforti (eds), La giurisprudenza italiana di diritto internazionale pubblico, vol. I, 1960-1987 (Napoli: Jovene, 1988) and P. Picone (ed.), La giurisprudenza italiana di diritto internazionale pubblico, vol. II, 1987-1997 (Napoli: Jovene, 1997). 
reject the claim. ${ }^{17}$ However, since this was a case brought against individuals, the 'political question' appeared to be intertwined with the question as to whether acts performed by persons acting on behalf of a state could be legally attributed to the state itself. In other words, the question was also raised before the courts as to whether individuals acting on behalf of the state enjoyed functional immunity for acts performed in an official capacity. Both issues were raised in order to request a dismissal of the claim. When the case was brought before the Supreme Court in 1957, the judges upheld the lower courts' decisions and rejected the applicants' claim ruling that the attack in question had to be considered a 'political act' and that it was a 'legitimate act of war'. ${ }^{18}$ This judgment, though, must be put against the background of the aftermath of World War II in Italy, which saw strong popular support for resistance movements. In addition, the reasoning of the Supreme Court in 1957 was rather detailed and elaborate as compared to Marković. The court at least endeavoured to give reasons for considering the partisans' attack on the Germans as lawful. ${ }^{19}$

Notwithstanding such a limited practice, according to a distinguished scholar it is correct to consider acts of war as 'political acts', hence exempt from judicial review. ${ }^{20}$ The application of the 'political question' doctrine to this class of acts would however seem controversial.

First of all, it is more appropriate to distinguish, on the one hand, between the general decision to participate in military operations and, on the other hand, single military actions subsequently undertaken as a follow-up to that decision.

Under the Italian Constitution, pivotal political decisions - such as a declaration of war or a decision to engage in military operations - pertain to parliament, which is also competent to authorize the government to exercise the executive powers required for implementing its decisions. ${ }^{21}$ By virtue of the discretion inherent in the exercise of such a crucial political function, as well as the basic principle of the separation of powers, these decisions cannot be questioned before a court of law.

On the contrary, specific military actions conducted by governmental authorities in

17 The background of the case is sadly well known in Italy. On 23 March 1944, in Rome, a bomb launched by Italian resistance fighters killed 33 German soldiers (and two civilians). The following day 335 (mainly civilians) were massacred as an act of reprisal by the German army. The relatives of some of the persons who died in the sanguinary reprisal summoned the perpetrators and those who ordered the attack against the German soldiers in order to obtain compensation for the damages suffered as a result of the violation both of the criminal military code and the criminal code. They also contented that the attack was brought without any prior authorization by a representative authority and that the authors of the attack, notwithstanding the imminent threat of a brutal reprisal against civilians, did not surrender themselves to the Germans.

18 Cassazione Sezioni Unite, 9 Luglio 1957 (Sansolini e altri c. Bentivegna e altri), in 59 Giurisprudenza italiana (1957), Parte I, Sez. I, at 1122.

19 In Sansolini, supra note 18, the court argued that (i) the attack could not, as such, entail the individual liability of those who had ordered and those who had accomplished it because it was to be ascribed to the Italian government, (ii) acts of war are in any case discretionary: they are to be considered 'political acts' and cannot therefore be a matter of adjudication and (iii) even if the attack complained of admittedly violated international law, this did not entail its unlawfulness according to Italian law.

20 P. Virga, Diritto amministrativo, Vol. II, (6th edn, Milano: Giuffrè, 2001), at 280.

21 See Articles 78, and 87, para. 9 of the Italian Constitution. 
the framework of previously authorized military operations are not to be considered as political decisions, but rather as executive activities undertaken in the implementation of a previous political decision. It follows that judicial review should not be automatically discarded with respect to single acts of war, since such acts - in addition to possibly breaching rules of international humanitarian law binding upon Italy may infringe, at the national level, on fundamental rights proclaimed in the Italian Constitution and complemented by the right to judicial redress.

Article 2 of the Italian Constitution ensures full protection of fundamental human rights and liberties. ${ }^{22}$ Through this provision, protection is not confined to the rights and liberties expressly enshrined in the Constitution itself, but is extended to every new or emerging fundamental right. Article 2 is indeed to be construed as being open-ended in nature: it ensures protection for all fundamental rights, including those which are granted to individuals by international rules binding upon Italy, either of a treaty or customary nature. In addition, Article 24 of the Italian Constitution explicitly includes among fundamental rights the right to an effective judicial remedy for the violation of anyone's rights or interests. ${ }^{23}$

It follows from this general legal framework that, whilst the political decision to participate in military operations may not per se be subject to judicial review, specific acts of war performed by the Italian government may be subject to adjudication. In particular, when it is contended that military actions - such as the bombing of RTS have impinged upon fundamental rights granted by Article 2 of the Italian Constitution or by any other constitutional provision granting fundamental rights, resort to the 'political question' doctrine would be highly questionable: judicial redress must instead be granted, as provided for in Article 24 of the Italian Constitution.

Moreover, international humanitarian law sets precise boundaries to state action. Italy has ratified both the four Geneva Conventions of 1949 and the two 1977 Additional Protocols, as well as many other treaties in the field of international humanitarian law. The Italian government is therefore bound to respect them when acting in warlike situations. The breach of rules contained in these treaties may also give rise to the violation of individuals' rights and interests, and should hence be subject to judicial review. ${ }^{24}$

In this perspective, as was rightly emphasized in the Resolution on 'The Activities of National Judges and the International Relations of their State' adopted by the Institut

22 Article 2: 'La Repubblica italiana riconosce e garantisce i diritti inviolabili dell'uomo, sia come singolo sia nelle formazioni sociali, ove si svolge la sua personalità, e richiede l'adempimento dei doveri inderogabili di solidarietà politica, economica e sociale.'

23 Article 24, para. 1: 'Tutti possono agire in giudizio per la tutela dei propri diritti e interessi legittimi.'

24 N. Ronzitti, supra note 4, at 685. In addition, one ought to also consider that many rules of these treaties and conventions have become customary international law. In the Italian system, customary international rules enjoy a 'constitutional guarantee': A. Cassese, 'Articolo 10', in G. Branca (ed.), Commentario della Costituzione italiana (Bologna/Roma: Zanichelli/Società editrice del Foro Italiano, 1975), 485-564. According to Article 10 of the Italian Constitution, customary rules are automatically transformed into corresponding internal rules binding all state officials, as well as all other individuals under Italian jurisdiction: international rules incorporated through this mechanism therefore enjoy constitutional rank. As a consequence, military operations are not constitutionally left to the discretion 
de droit international in $1993,{ }^{25}$ national courts 'when called upon to adjudicate a question related to the exercise of executive power, should not decline competence on the basis of the political nature of the question if such exercise of power is subject to a rule of international law' (Article 2). The application of the 'political question' doctrine to acts of war was discussed during the preparatory works of this Resolution. ${ }^{26}$ The suggestion relating to the role of national judges is reflected in the Final Report accompanying the text adopted. It is worth quoting a passage which perfectly illustrates the matter discussed here:

It was held in the Commission that if it is 'absurd' for a court to stop a war, this does not mean that a court cannot grant compensation ( ... ) we think one can reasonably propose that the courts have the power to decide on compensation for damages caused to private persons as a consequence of a war or of a use of force contrary to international law. ${ }^{27}$

Not surprisingly, some of the propositions set forth above were utilized by the Italian government itself, when answering questions posed by the judges of the ECHR related to the decision on admissibility in Banković. ${ }^{28}$ The Italian deputy co-agent to the ECHR presented the observations of the Italian government following some questions addressed specifically to Italy by Judge Hedigan. He explained, in a clear and detailed manner, that in principle no governmental authority is shielded from judicial scrutiny, the only exception being 'political acts'. ${ }^{29}$ More specifically, he stated:

... a declaration of war, or the decision to take part in a military operation, could be considered a political act. The conclusion might nevertheless be quite different in respect of a specific action (or even a specific decision) pursuant to the declaration of war or taken within the framework of the military operation as a whole. Thus, it is perfectly possible to argue that, while the participation of Italy in the military campaign in the FRY is in itself a political act, and is as such shielded from judicial scrutiny, this is no bar to judicial review in respect of each single operation carried out within it (such as the bombing of the RTS building) on the alleged grounds that it was unlawful and caused unjust prejudice to the rights of any given private person. (emphasis added)

of political or military organs. Courts should have the possibility to review government actions and determine whether they are inconsistent with customary international rules thereby exceeding the authority granted by the Constitution or through the Constitution (that is, indirectly violating Article 10 of the Constitution).

25 Resolution adopted on 7 September 1993, see 65 (II) Annuaire de l'Institut de droit international (1994) $318-323$.

26 The question was addressed in more general terms also in the Preliminary Report (Rapporteur, Conforti). In reviewing the 'political question' doctrine as an obstacle to the application of international law by national judges, the Rapporteur underlined the strong need to establish the conditions under which the exception of the 'political question' doctrine should be rejected. He indicated precisely two conditions: (i) the existence of a precise and complete international obligation and (ii) the non-existence of an authorization on the part of the legislative branch. See the Preliminary Report in 65 (I) Annuaire de l'Institut de droit international (1993) 327-339. In other words, national judges should not be prevented from reviewing their government's action when there is an international obligation to be respected and when parliament did not expressly authorize the government's conduct.

27 For the Final Report, see 65 (II) Annuaire, supra note 25, at 437.

28 See supra, note 2.

29 See Application N 52207/99 Banković and others v. Belgium and others, Observations of the Italian Government, submitted by Francesco Crisafulli, Deputy Co-agent at the ECHR (on file with the author). 
In addition, the Italian representative stressed that judicial proceedings, if any, relating to Banković - hence also encompassing the bombing of RST on 23 April 1999 like in Marković - would be definitely governed by Italian law: as the Italian jurisdiction embraces any case where the defendant has his legal residence in Italy, a case involving the Italian government as the defendant would obviously fall under Italian jurisdiction. Concluding as to the law governing such proceedings in Italy, the Italian deputy co-agent finally stated that: 'the Italian law would certainly rule the proceedings in Italy, both as to the procedure and as to the merits, at least if the claimant asks that such be the case'. This was indeed the case in Marković. One is left with the impression that, somewhat paradoxically, in Marković the Supreme Court was more persuaded of the necessity to shun judicial proceedings than some of the representatives of the government against which the claim was brought (at least those representing Italy at the ECHR).

It would therefore seem that the Supreme Court's decision was not convincingly argued under Italian law. It expanded the application of the 'political question' doctrine beyond the limits so far accepted and, certainly, beyond the limits that should be respected in order to ensure compliance with international law. It must be taken into account that, besides the international obligations that may have been violated through the bombing of RTS, there could also exist a specific obligation to indemnify victims of humanitarian law violations, as claimed by the applicants in Marković.

\section{Are States Bound under International Law to Compensate Individuals for Damages Suffered as a Result of Humanitarian Law Violations?}

\section{A. Article 91 of 1977 First Additional Protocol and Article 3 of the 1907 Hague Convention IV on Land Warfare}

As recalled above, Article 24 of the Italian Constitution lays down the right to an effective judicial remedy. This right is backed up by a judicial system allowing for a private right of action before the judiciary. Accordingly, if Italy is bound by an international rule which imposes upon states an obligation to compensate individuals for damages suffered as a result of humanitarian law violations, and which confers on the victims the right to seek compensation, this rule may be considered self-executing. Individuals may thus bring a claim before Italian courts asking them to act upon that international rule. ${ }^{30}$ The Supreme Court, resorting to the 'political act' doctrine, refrained from establishing whether any obligation to pay compensation for damages

30 For a sharp analysis of the right to reparation in favour of injured individuals within domestic legal orders with respect to human rights see, R. Pisillo-Mazzeschi, 'International Obligations to Provide for Reparation Claims?', in A. Randelzhofer, C. Tomuschat (eds), State Responsibility and the Individual, Reparation in Instances of Grave Violations of Human Rights (The Hague/Boston/London: Nijhoff, 1999) 149-172. The author concludes that international rules having a self-executing character may well impose upon a state an obligation of reparation towards private individuals, who can enforce their right before domestic courts. 
caused to individuals and any corresponding right of the victims to seek compensation arise from international humanitarian law rules binding upon Italy. Such an obligation could derive from Article 91, Protocol I, ratified by Italy in 1986. The question deserves close examination.

Article 91 - which almost exactly reproduces Article 3 of the 1907 Hague Convention on Land Warfare IV (Hague Convention IV) - provides that:

A Party to the conflict which violates the provisions of the Conventions or of this Protocol shall, if the case demands, be liable to pay compensation. It shall be responsible for all acts committed by persons forming part of its armed forces.

This rule may simply be read as enshrining one of the basic principles of state responsibility: the state that performs a wrongful act must provide reparation, in the form of compensation if the case so demands. Under the law of state responsibility, reparation is provided to the 'injured' state, and not directly to the victims of a wrongful act. Accordingly, compensation for personal injuries and damages to individuals is often dealt with through diplomatic protection, i.e. at the interstate level: states may claim compensation on behalf of their officials or nationals for any material or moral damage suffered following unlawful acts by another state.

However, the law of state responsibility does not 'exclude the possibility that an internationally wrongful act may involve legal consequences in the relations between the State responsible for that act and persons or entities other than the States'. ${ }^{31}$ The Draft Articles on the Responsibility of States for International Wrongful Acts, adopted on second reading by the International Law Commission (ILC) in 2001, do not deal with the legal consequences of an internationally wrongful act other than between states. However, the text adopted is clearly 'without prejudice to any right, arising from the international responsibility of a State which may accrue directly to any person or entity other than the State'. ${ }^{32}$ The ILC commentary explicitly states that there are cases (mainly but not exclusively in the framework of human rights treaties) where individuals are the ultimate beneficiaries of international rules and, hence, the holders of the corresponding rights. ${ }^{33}$

Article 91, Protocol I, itself - whose heading is 'Responsibility' - does not exclude the possibility that individuals be its beneficiaries. A careful interpretation of this provision is therefore necessary to verify whether it (i) establishes states' liability towards individuals and (ii) entitles individuals directly to seek compensation through their domestic courts.

It is common knowledge that when construing a treaty rule, one must first look at

31 Commentary to Article 28, in Report of the International Law Commission (ILC), at 214, available at http://www.un.org/law/ilc/texts/State_responsibility/responsibility_commentaries(e).pdf\#pagemode= bookmarks (visited April 2003). On state responsibility for humanitarian law violations see M. Sassòli, 'State Responsibility for Violations of International Humanitarian Law', 84 Revue Internationale de la Croix Rouge, n. 846 (2002) 401-433.

32 Article 3, para. 2, Draft Articles on the Responsibility of States for International Wrongful Acts, available http://www.un.org/law/ilc/texts/State_responsibility/responsibilityfra.htm (visited April 2003).

33 ILC Commentary to Article 33 of the Draft Articles, supra note 31, at 234. 
the ordinary meaning of the terms used in the treaty. ${ }^{34}$ The term 'compensation', used in Article 91, often refers to payment of damages to individuals; nothing in the wording of the provision aims at excluding that a state responsible shall directly indemnify the victims. In fact, the beneficiaries of the payment are not spelt out in the provision: neither states nor individuals are mentioned. To determine the meaning of a specific provision that is obscure or ambiguous, one may resort to supplementary means of interpretation, including the preparatory works. ${ }^{35}$ However, the preparatory works of the Diplomatic Conference on the Reaffirmation and Development of International Humanitarian Law Applicable in Armed Conflicts (1974-1977) which led to the adoption of the two Additional Protocols to the Geneva Conventions of 1949 - provide no assistance in the case at issue, because they do not contain any detailed explanation of the meaning of Article 91.

The Vietnamese delegate, when introducing the proposed article, said that it was meant to reaffirm, inter alia, the principle of reparation enshrined in Article 3 of the Hague Convention IV. ${ }^{36}$ Most probably, Vietnam and the other countries sponsoring the draft text had in mind, in the first place, reparation due to states. Nonetheless, this intention was not explicitly expressed and the issue of compensation to individuals was not raised in the drafting process of the provision, which eventually became Article 91.

It is thus appropriate to go back to the drafting history of the progenitor of Article 91, that is Article 3 of the Hague Convention IV, evoked in the preparatory works of Protocol I. As mentioned above, the text of Article 3 is almost identical to that of Article 91 and does not contain any express indication as to its beneficiaries. ${ }^{37}$ However, the issue of states' obligations to indemnify enemy or neutral persons for damages suffered as a result of acts committed by their armed land forces in contravention of the regulations on land warfare, was explicitly raised during the

34 As provided for in Article 31 of the 1969 Vienna Convention on the Law of Treaties: 'a treaty shall be interpreted in good faith in accordance with the ordinary meaning to be given to the terms of the treaty in their context and in the light of its object and purpose'.

35 According to Article 32 of the Vienna Convention on the Law of Treaties: 'Recourse may be had to supplementary means of interpretation, including the preparatory works of the treaty and the circumstances of its conclusion, in order to confirm the meaning resulting from the application of Article 31, or to determine the meaning when the interpretation according to Article 31: (a) leaves the meaning ambiguous or obscure; or (b) leads to a result which is manifestly absurd or unreasonable.' Articles 31 and 32 are considered to correspond to customary international rules.

36 See the Official Records of the Diplomatic Conference on the Reaffirmation and Development of International Humanitarian Law Applicable in Armed Conflicts, Geneva (1974-1977), vol. 9, 355; see also F. Kalshoven, 'State Responsibility for Warlike Acts of the Armed Forces. From Article 3 of Hague Convention IV of 1907 to Article 91 of Additional Protocol I of 1977 and Beyond', 40 International and Comparative Law Quarterly (1991) 827-858 and C. Greenwood, 'International Humanitarian Law (Laws of War), Revised Report for the Centennial Commemoration of the First Hague Peace Conference 1899', in F. Kalshoven (ed.), The Centennial of the First International Peace Conference, Reports and Conclusions (The Hague/Boston/London: Kluwer Law International, 2000) 161-259, at 251.

37 Article 3: 'A belligerent party which violates the provisions of the said Regulations shall, if the case demands, be liable to pay compensation. It shall be responsible for all acts committed by persons forming part of its armed forces.' 
Second Hague Peace Conference (1907), when the original text of the 1899 Convention on land warfare with Annexed Regulations was amended. ${ }^{38}$

In the Second Commission (1st Sub-Commission) of the Conference, the German delegation proposed the introduction of two new articles concerning states' liability to pay damages caused by any breach of the Regulations. The first proposal established that belligerent parties must be responsible for all acts committed by their armed forces and also provided that belligerent parties had the duty to indemnify neutral persons for any loss suffered as a result of violations of the regulations. The second proposed article provided instead that the issue of compensation for the victims of violations belonging to the adverse party would be dealt with on the conclusion of peace. ${ }^{39}$ In the drafting process the distinction between neutral persons and persons belonging to the adverse party was abandoned and the two proposed articles became Article 3, as finally adopted. ${ }^{40}$

Although the beneficiaries of compensation are not mentioned in the final wording of the article, it is apparent that the German delegate intended to refer to individuals as victims of breaches of the Convention and Annexed Regulations. The principle of states' liability towards private persons was not opposed by other delegations, which agreed to the existence of such an obligation to compensate damages caused to individuals. ${ }^{41}$ None of the delegates, however, pronounced on whether it was for states to claim damages on behalf of their nationals, or for the victims themselves to directly seek compensation. The position expressed by the British delegate, Sir Lord Reay, seems particularly interesting because while unconditionally asserting the existence of an obligation incumbent upon states to indemnify individuals, he refrained from clearly specifying the legal beneficiaries of the corresponding right and anticipated the potential difficulties in the implementation of such an obligation:

Je ne conteste pas l'obligation qui existe pour une Puissance belligérante de dédommager ceux qui ont été victimes de la violation des lois et coutumes de la guerre et la Grande-Bretagne ne désire aucunement se soustraire à ses obligations. Je ferai seulement observer qu'il est souvent fort difficile de constater cette violation et la portée du dommage causé. Proclamer le principe est facile, mais il est bien difficile de l'appliquer sans soulever des contestations qui nuisent aux bons rapports des Etats qui doivent résoudre le problème. ${ }^{42}$

Deuxième Conférence Internationale de la Paix, La Haye 15 Juin-18 Octobre 1907, Actes et Documents, 3 vols (hereinafter Actes et Documents).

39 The proposed articles in the original French version read: 'Article 1: La Partie belligérante qui violera les dispositions de ce Règlement, au préjudice de personnes neutres, sera tenues de dédommager ces personnes du tort qui leur a été causé. Elle sera responsable de tous actes commis par les personnes faisant partie de sa force armée. La fixation du dommage causé et de l'indemnité à payer, à moins qu'une indemnisation immédiate en espéces n'ait été prévue, pourra être remise à plus tard, si la Partie belligérante estime que cette fixation est incompatible, pour le moment, avec les opérations militaires; Article 2: En cas de violation au préjudice de la Partie adverse, la question de l'indemnisation sera réglée lors de la conclusion de la paix.', Annexe 13, Actes et Documents, supra note 38, vol. III, at 247.

40 The doubts expressed by various delegations were precisely focusing on the distinction between neutral and enemy persons that was eventually dropped in the final version of the article, ibid.

41 Ibid., at $144-149$.

42 Ibid., at 147. 
Analysis of the preparatory works thus seems to indicate that the introduction of Article 3 had a twofold purpose: (i) to establish that every belligerent party must be liable for all violations of the regulations committed by its armed forces and (ii) to establish, as a consequence of these violations, an obligation for state parties to pay compensation for damages caused to neutral or enemy persons. ${ }^{43}$ But there is still ambiguity with respect to the right of individuals to directly seek and obtain compensation.

In 1977, states restated the rule on states' responsibility in the same terms: Article 91, Protocol I, as recalled above, almost literally reproduces Article 3 of the Hague Convention IV, with minor changes in language. In accordance with the interpretation of Article 3 given above, it may thus be contended that Article 91 also lays down a rule binding on the contracting parties to the effect that they are mandated to pay damages caused to individuals by humanitarian law violations committed by their armed forces. It still remains unclear whether individuals have a corresponding right to seek compensation within domestic legal orders.

To achieve a satisfactory construction of the rule, it appears necessary to establish how the rule has been implemented in practice. ${ }^{44}$ Indeed, subsequent state practice is an important element one should take into account when interpreting a treaty provision and, a fortiori, when trying to assess if this provision has turned into a customary rule.

\section{B. State Practice, the Subsequent Interpretation of Article 3 of the Hague Convention IV and Article 91, Protocol I, and Customary International Law}

As predicted by the British delegate in 1907, implementation of Article 3 has posed several problems and states have proved unready to allow individuals to seek directly the payment of damages. They opted for an interstate approach: the issue of compensation for damages caused to individuals as a result of humanitarian law violations has essentially been handled through mechanisms resting on agreements between states. On this score, states have adopted two main solutions. On the one hand, compensation matters have often been dealt with in peace treaties through lump-sum agreements between states, payment being subsequently distributed to the victims. On the other hand, mixed arbitral tribunals or commissions with the task to

43 The preparatory works of the Second Hague Peace Conference have been carefully analysed by a distinguished scholar who concluded that Article 3 'specifically addresses the liability of a State to indemnify enemy or neutral persons for damages incurred as a result of acts committed by members of its armed land forces in contravention of the Regulations', see F. Kalshoven, supra note 36, at 833. See also C. Greenwood, supra note 36, at 251 and S. Boelaert-Suonimen, 'Iraqi War Reparations and the Laws of War: a Discussion of the Current Work of the United Nations Compensation Commission with Specific Reference to Environmental Damage During Warfare' 50 Zeitschrift für öffentliches Recht (1996) 225-316, at 294 (both works are mainly based on Kalshoven's analysis of the preparatory works of Article 3).

44 According to Article 31, para. 3 of the Vienna Convention on the Laws of Treaty: 'There shall be taken into account, together with the context: (...) (b) any subsequent practice in the application of the treaty which establishes the agreement of the parties regarding its interpretation.' 
settle private compensation claims have been established by peace agreements, as happened for instance with the treaty of Versailles in $1919^{45}$ or, much later, with the UN Compensation Commission, established by the UN Security Council. ${ }^{46}$ In the framework of these global compensation mechanisms, no distinction is provided between war damages in general and damages caused as a result of humanitarian law violations. $^{47}$

Therefore, practice is scant as regards private complaints seeking compensation for damages suffered as a result of breaches of humanitarian law, and specifically based on Article 3 Hague Convention IV or Article 91, Protocol I.

The majority of existing cases relate to payment of compensation for damages caused during World War II. Several applications were filed against the government of Japan, ${ }^{48}$ both by Japanese and foreign claimants, albeit not always relying on Article 3 of the Hague Convention IV. A survey of claims brought on behalf of slave labourers, comfort women (i.e. women forced into prostitution by Japanese troops), torture victims, Koreans forced into military duty, Chinese nationals who were victims of biological experiments, and Allied prisoners of war, shows that they have all been dismissed. $^{49}$

Japanese tribunals have argued that either (i) the right of individuals to seek compensation was waived by peace treaties concluded with various countries; or (ii)

45 See Treaty of Versailles, Articles 231-247 and Annexes - Reparations.

46 On the work of the UN Compensation Commission, see Boelaert-Suominen, supra note 43; A. Gattini, 'La riparazione dei danni di guerra causati dall'Iraq' 76 Rivista di diritto internazionale (1993) 1000-1046; V. Heiskanen and R. O’Brien, ‘UN Compensation Commission Panel Sets Precedents on Government Claims', 92 American Journal of International Law (1998) 339-350; D. Caron and B. Morris, 'The United Nations Compensation Commission: Practical Justice, not Retribution', 13 European Journal of International Law (2002) 183-200; A. Gattini, 'Old Rules, New Procedures on War Reparations', ibid., 161-182.

47 For a comprehensive survey on the reparation of war damages see P. d'Argent, Les réparations de guerre en droit international public. La responsabilité des Etats à l'épreuve de la guerre (Bruxelles/Paris: Bruylant/L. G. D. J., 2002).

48 As in the well-known Shimoda case, see 8 The Japanese Annual of International Law (1964) 212-252. On the Shimoda case see R. Falk, 'The Shimoda Case: A Legal Appraisal of the Atomic Attacks Upon Hiroshima and Nagasaki', 59 American Journal of International Law (1965) 759-793. In 1963 the Tokyo District Court handed down a judgment concerning the use of nuclear weapons in World War II. The plaintiffs claimed that dropping atomic bombs on Hiroshima and Nagasaki violated international law, and consequently they asserted their right to obtain compensation from the US government. However since the Japanese government, through the San Francisco Peace Treaty of 1951, waived its right to claim, the claimants brought their claim against the Japanese government itself. The Tokyo court ruled that the atomic bombing was indeed illegal, but at the same time dismissed the compensation claim affirming that the claimants had no right to the payment of damages from the Japanese government.

49 Some of these judgments have been translated into English and are available in The Japanese Annual of International Law. Detailed references may be found in M. Igarashi, 'Post-War Compensation Cases, Japanese Courts and International Law', 43 The Japanese Annual of International Law (2000) 45-82. The author estimates that there are more than 50 cases relating to post war compensation as of December 2000. For most recent cases, such as that relating to the notorious Unit 731, including Japanese soldiers who carried out biological experimentation in China, see press reports, such as: 'Tokyo Court Confirms Japan Used Germ Warfare in China. Compensation Denied for Deaths Caused by Diseases Spread in WWII', by D. Struck, Washington Post, Wednesday, 28 August 2002, p. A15. 
the right to seek compensation could not to be exercised directly but only through the traditional means of diplomatic protection; or (iii) passage of time barred the exercise of jurisdiction. To give a fitting example concerning Article 3 of the Hague Convention IV: in a decision concerning claims for compensation from Japan arising from injuries suffered by former prisoners of war and civilian internees of the Netherlands, the Tokyo District Court interpreted Article 3 as not conferring on individuals the right to seek payment of damages in the assailant nation's domestic courts. ${ }^{50}$

It must be stressed however that some Japanese courts, while dismissing the applicants' claims, have left room for possible different interpretations. For instance, in 1996 the Tokyo High Court, while rejecting the existence of a private right to compensation, grounded its decision on customary international law existing at the time of the incident complained of, that is to say during World War II. At present, the court implicitly admitted, the existence of such a rule could not be excluded. ${ }^{51}$

In addition, in April 1998, in the first judgment of this kind, a Japanese court ruled that the Japanese government must pay compensation to three South Korean women forced to have sexual intercourse with Japanese soldiers during World War II. ${ }^{52}$ The ruling was however overturned by a higher court, which held that all compensation matters had been dealt with in peace treaties after the war. However, the judgment of first instance had marked an important attempt in a different direction.

Claims have also been brought against the German government, both before US

50 '... Even though it is recognized that in the drafting process of Article 3 of the Hague Convention the Article targeted relief for individuals suffering injury, in the deliberation process and drafting of Article 3 we were unable to find any facts based in the statements made by the delegates of the contracting nations or other like sources that inferred that the contracting nations intended, or even agreed, to enact provisions that enabled individuals to seek compensation directly from the assailant nation. ( ...) we may assume that concerning the relief of individual victims, all parties naturally presumed the exercising of diplomatic protective rights,': Tokyo District Court (Civil Division n 6, case N 1218-1994), 30 November 1998, reprinted in 42 The Japanese Annual of International Law (1999) at 143.

51 'When the incident occurred, there was no evidence of any general practice, or the existence of opinio juris that when a state acts in violation of the obligation of international human rights law or humanitarian law, that state has the responsibility of compensating for the damages of any individual who was a victim. Therefore, international customary law against which the applicants' claim did not exist at the time of the incident' (emphasis added). The decision in X et al. v. The State of Japan, Tokyo High Court (7 August 1996) is reprinted in 40 The Japanese Annual of International Law (1997) at 116-117.

52 The Kanpu judgment, Yamaguchi District Court, Shimonoseki Branch (27 April 1998), quoted by M. Igarashi, supra note 49, at 47. The court's decision held the Japanese government liable for international law violations and ordered payments of 300,000 yen each to three women nationals of the Republic of Korea. 
courts - for instance in Princz v. the Federal Republic of Germany ${ }^{53}$ - and Greek courts, as happened in Prefecture of Voivoitia v. the Federal Republic of Germany. ${ }^{54}$

In sum, national courts have very rarely awarded to individuals compensation for damages. Judges either (i) grounded their decisions to reject claims on the law of state immunity from jurisdiction or on previous peace agreements waiving individual rights, thus also avoiding the need to pronounce on the obligation of states (either conventional or customary) to pay compensation directly to victims of breaches of international humanitarian law or (ii) interpreted the rule in question as not conferring on the individual the right to seek payment of damages. ${ }^{55}$

What conclusions can be drawn as to the obligation to compensate individuals' damages caused by humanitarian law violations? State practice shows that the rule enshrined in Article 3 Hague Convention IV and in Article 91, Protocol I has been interpreted as an interstate obligation: states have reserved the right to negotiate the awarding of compensation to individuals through subsequent agreements. ${ }^{56}$

If the conclusion is thus warranted that the rules in question have not been interpreted as bestowing a right upon individuals, it must a fortiori be held that it is not possible to infer from state practice that a customary rule granting such right has evolved.

53 As to the Princz case, the District Court of DC initially affirmed its jurisdiction over the case, but the judgment was reversed and the case dismissed by the Court of Appeals which affirmed the lack of jurisdiction. As to the non-self-executing character of Article 3 of the Hague Convention IV (1907) see also the reasoning of the US Court of Appeals, Fourth Circuit in Goldstar (Panama) S.A. v. United States, 16 June 1992, 967 F 2d 965, at para. 7: 'International treaties are not presumed to create rights that are privately enforceable ( . . ) Courts will only find a treaty to be self-executing if the document, as a whole, evidences an intent to provide a private right of action. ( . . ) The Hague Convention does not explicitly provide for a privately enforceable cause of action. Moreover, we find that a reasonable reading of the treaty as a whole does not lead to the conclusion that the signatories intended to provide such a right.'

54 The case brought before Greek courts was initially successful (both before the district court of Levadia and the Areios Pagos, the Greek Supreme Court), despite somewhat convoluted legal reasoning by both courts. Lately, however, this case also has been dismissed. For detailed references see the article by Gattini in this symposium, supra, 348-367.

55 In 1996, in a decision concerning a compensation claim for slave labour during World War II, the German Constitutional Court held obiter that a state that has violated international law may allow individuals to bring compensation claims before its domestic courts. However, the decision contains no reference to an international law rule accruing to individuals the right to seek and obtain compensation for injuries suffered as a result of humanitarian law violations. Case N. 2 BvL 33/93 (Forced labour), Second Chamber of the Constitutional Court, 13 May 1996, 94 BverfGe at 315.

56 In this sense, see D'argent, supra note 47, at 784-791. Contra see F. Kalshoven, supra note 36; C. Greenwood supra note 36; E. David, Principes de droit des conflits armés (2nd edn, Bruxelles: Bruylant, 1999), at 570. 


\section{The Need for a New Interpretation Reconciling State Practice with the Right of Individuals to Seek and Obtain Compensation}

However, some general considerations seem appropriate and may lead one to propound a different conclusion, at least in particular circumstances.

Many reasons have contributed to the adoption of comprehensive solutions agreed between states for compensation to individuals for war damages and damages caused by breaches of humanitarian law: the large number of cases to be settled in the aftermath of conflicts, the necessity of reparation without delay, and the opportunity to address the issue in the overall context of post conflict agreements, also taking into account the economic capacity of states. Admittedly, balanced and effective solutions can hardly be reached through the individualization of compensation mechanisms in cases where states have to deal with massive episodes of damages suffered by the civilian population.

Therefore, reluctance of states to admit their legal responsibility towards victims of humanitarian law violations committed by their armed forces is not the only reason (and perhaps not the most important) behind the attitude of states.

Some of these considerations were set forth, in a very clear manner, by the US Court of Appeals, DC Circuit in Tel-Oren v. Lybian Arab Republic, with reference to Article 3 of the Hague Convention IV:

The Hague Conventions similarly cannot be construed to afford individuals the right to judicial enforcement. Although the Conventions contain no language calling for implementing legislation, they have never been regarded as law private parties could enforce. If they were so regarded, the code of behavior the Conventions set out could create perhaps hundreds of thousands or millions of lawsuits by many individuals ( ... ) Those lawsuits might be far beyond the capacity of any legal system to resolve at all ( ... ). Finally, the prospect of innumerable private suits at the end of a war might be an obstacle to the negotiation of peace and the resumption of normal relations between nations. It is for these reasons that the Conventions are best regarded as addressed to the interest and honor of belligerent nations, not as raising the threat of judicially awarded damages at war's end. ${ }^{57}$

Recent agreements concluded for compensation to Holocaust victims seem to indicate that the threat of countless lawsuits may force states to recognize their liability towards individuals, and to award compensation for damages and injuries caused to the victims in cases where they initially denied this possibility. The results lately obtained by the Holocaust Restitution Movement as to compensation for wartime 'labour slaves' may be seen in this perspective. In 2001, following a substantial number of compensation claims filed in US courts, Germany entered into agreements establishing funds for 'labour slaves'. These agreements are unique since they provide for voluntary payments ${ }^{58}$ by Germany, which, however, has accepted them as binding commitments. The German Prime Minister conceded in 1999 that supra note 53.

58 Payments are made both to other countries and to victims' organizations. 
the threat of American litigation finally brought Germany to reverse its previous position on the issue. ${ }^{59}$

The Austrian government also established a compensation scheme for 'labour slaves ${ }^{90}$ and the Norwegian government is reportedly thinking of a compensation programme for Norwegian war children, ${ }^{61}$ along the lines of what other countries have already done.

In this way, individuals who were not compensated through post war agreements and subsequent distribution schemes finally obtained reparation for the injuries suffered as a result of serious violations of humanitarian law violations during World War II.

Where peace treaties or compensation agreements have not been concluded and where there is a substantial likelihood that they may never be concluded, one may wonder whether it would not be appropriate for national judges to begin applying the rule on states' liability as a rule accruing to individuals the right to seek and obtain compensation for damages incurred as a result of humanitarian law violations.

The rule so construed would grant individuals not compensated through interstate agreements or through the establishment of specific funds by governments, an enforceable right to seek and obtain payment for damages suffered. It could also prove to be an important means for (i) prompting states to establish compensation schemes where they are trying to discharge their responsibility and (ii) encouraging future compliance with the laws of war, at least in order to avoid the likelihood of compensating damages.

This interpretation would be in full conformity with current trends in various fields of international law.

It is common knowledge that, since 1945, individuals have been progressively

59 Prime Minister Schroeder announced in February 1999 the establishment of a fund for those subjected to slave labour explicitly stating that the fund was established 'to counter lawsuits, particularly class action suits, and to remove the basis of the campaign being led against German industry and our country'; see R. Cohen, 'German Companies Set up Fund for Slave Laborers under Nazis', New York Times, 7 February 1999, at A1. See also G. McCool, 'U.S. Judge Helps Clear Holocaust Payment Obstacle', New York Times, 16 May 2001, at A1. For a previous agreement between Germany and the US on compensation to victims of the Nazi persecution, see the text of the Agreement between the Government of the Unites States of America and the Government of the Federal Republic of Germany concerning Financial Benefits to Certain United States Nationals who were victims of National Socialist Measures of Persecution, 19 September 1995, 35 ILM (1996) at 193.

60 See 54 Austrian Information (March 2001), available at http://www.austria.org/oldsite/mar01/ fund.html (visited April 2003).

61 In this case a failed lawsuit may instead lead to a compensation programme. Some Norwegian war children (who were part of the Nazi lebensborn programme) filed an application against the Norwegian government seeking compensation for infringements committed against them during their childhood: the Oslo City Court rejected their claim. The victims group decided to appeal the decision. In the meanwhile, in a landmark decision the Norwegian parliament's justice committee decided to lay the ghosts of its 1940-1945 occupation to rest by ruling that the government should 'make amends' by the end of next year. Its official recommendation is being considered by the ruling coalition. See, 'Norway's abused war children move step closer to compensation', The Guardian, 7 December 2002. 
recognized as beneficiaries of a number of rights deriving from international rules. ${ }^{62}$ They have correspondingly been entitled to bring claims against states within their domestic legal orders or even before international bodies created by treaty, mainly in the human rights field.

More specifically, the right to restitution, compensation and rehabilitation for victims of grave violations of human rights and humanitarian law has been the object of careful attention by UN bodies ${ }^{63}$ and other organizations. The UN Commission on Human Rights appointed, in 1989, an independent expert to prepare a draft text containing principles and guidelines on the right to reparation for victims of human rights and humanitarian law violations. ${ }^{64}$ The Basic Principles and Guidelines on The Right to a Remedy and Reparation for Victims of Violations of International Human Rights and Humanitarian Law, adopted in 2000 and also based on the observations of governments, provide that the 'remedies for violations of international human rights and humanitarian law include the victim's right to: (a) Access justice; (b) Reparation for harm suffered; and (c) Access to the factual information concerning the violations'. ${ }^{65}$

62 See the International Committee of the Red Cross Commentary to Protocol I, where it is stated that: "Those entitled to compensation will normally be Parties to the conflict or their nationals, though in exceptional cases they may also be neutral countries, in the case of violation of the rules on neutrality or of unlawful conduct with respect to neutral nationals in the territory of a Party to the conflict. Apart from exceptional cases, persons with a foreign nationality who have been wronged by the unlawful conduct of a Party to the conflict should address themselves to their own government, which will submit their complaints to the Party or Parties which committed the violation. However, since 1945 a tendency has emerged to recognize the exercise of rights by individuals.' (Emphasis added.) ICRC Commentary to Article 91, Protocol I, available on the ICRC website, at www.icrc.org

63 The UN General Assembly (UNGA) adopted in 1985 a Declaration of Basic Principles of Justice for Victims of Crime and Abuse of Power. One of the basic principles indicated therein is the right of the victims to obtain restitution or compensation.

64 With resolution 1989/13 of 31 August 1989, the Sub-Commission on Prevention of Discrimination and Protection of Minorities (now Sub-Commission on Human Rights) appointed Professor Van Boven as a Special Rapporteur to consider the issue of restitution, compensation and rehabilitation of gross violations of human rights and humanitarian law fundamental freedoms and to prepare draft guidelines on this question in the light of existing relevant international instruments. The Special Rapporteur submitted the final version of the principles in 1997 (UN doc. E/CN.4/1997/104, annex). The draft basic principles and guidelines were sent to the Commission on Human Rights where they were carefully examined and commented on by states, intergovernmental and nongovernmental organizations. In 1998, the Commission on Human Rights decided to appoint Professor Cherif Bassiouni as an independent expert to prepare a revised version of the draft basic principles taking into account the comments and views of states, intergovernmental and nongovernmental organizations and to submit it to the Commission at the 55th session with a view to its adoption by the UNGA. Professor Bassiouni submitted the final report in January 2000 (UN doc. E/CN.4/2000/62).

65 Other important documents establishing the existence of such a rule in the field of international humanitarian law include, for instance, the final report of Ms. McDougall, the Special Rapporteur appointed by the UN Sub-commission on UN Human Rights on 'Systematic rape, sexual slavery and slavery-like practices during armed conflict' (which also contains an analysis of the legal liability of the government of Japan for 'comfort women stations' established during the World War II. See UN doc. E/CN.4/Sub.2/1998/13). It is also worth mentioning the Hague Appeal For Peace and Justice for the 21st Century, brought before the UNGA and suggesting the adoption of a Draft Instrument establishing an Individual Complaints procedure for Violations of International Humanitarian Law, inspired at the 
The right of victims to seek reparation for the harm suffered has also emerged in the field of international criminal law. The issue of reparation for victims of the most serious crimes under international law has proved to be crucial ${ }^{66}$ at the negotiating table of the Statute of the International Criminal Court. It has been the object of intense negotiations that led to the introduction, in the final text of Article 75, of the victims' right to reparation. ${ }^{67}$ As far as state responsibility is concerned, the drafting history of Article 75 clearly shows that options providing for the court to issue binding orders or even recommendations to states were discussed, but were subsequently rejected in the final version of the article. As has been stressed: 'a significant number of delegations were not prepared to accept the notion of State responsibility to, or in respect of, victims'. ${ }^{68}$ Although it was probably not deemed appropriate to entrust the ICC, established to adjudicate individual criminal liability, with tasks relating to the implementation of state responsibility, the negotiations clearly showed that a number of states were indeed ready to accept their responsibility toward individuals (including responsibility for grave violations of humanitarian law) and to face the possibility of receiving a binding order of the ICC on the matter of compensation to individuals.

From this perspective, it seems incongruous to hold that in the case of humanitarian law violations the victims may claim damages only through their national state, or by bringing a claim against the state official found guilty of the breach (thus

successful individual complaint procedures in the human rights law context. The aim of this instrument would be to provide a suitable mechanism also to individuals who cannot address themselves to an appropriate domestic judicial system or where other reasons are barring courts from pronouncing on presumed violations.

66 The issue of compensation to victims was not addressed by the UN Security Council when the Statutes of the two ad hoc tribunals for the Former Yugoslavia and Rwanda were adopted. Both ICTY and ICTR Statutes contain an article allowing the trial chambers to order the return of any property and proceeds unlawfully acquired by criminal conduct to the rightful owner (Article 24,3 ICTYSt) but no provision relates to compensation for the victims. However, the drafters of the rules of procedure decided to adopt Rule 106 establishing that the tribunals have the right to transmit the judgment to the relevant national authorities and stating that the victims may bring an action in a national court. In addition, stating that the judgment shall be binding upon national courts as to the criminal responsibility of those convicted, the rules imply that national courts have to act accordingly: if the case demands, national courts shall then award compensation, this is the logical conclusion that can be drawn.

67 Article 75 provides that the court may award compensation to the victims taking into account the scope and extent of any damage, loss and injury. The victim himself or herself is entitled to apply to the court for an order awarding compensation for the damages suffered. On the issue of reparations to victims, see C. Jorda and J. de Hemptinne, 'The Status and Role of the Victim', in A. Cassese, P. Gaeta and J.R.W.D. Jones (eds), The Rome Statute of the International Criminal Court: A Commentary (Oxford: Oxford University Press, 2002), vol. II, 1387-1420; F. Lattanzi and W.A. Schabas, Essay on the Rome Statute of the International Criminal Court, vol. I (Ripa Fagnano Alto: Sirente, 1999), 303-310; C.P.J. Muttukumaru, 'Reparations to Victims', in R.Y. Lee (ed.), The International Criminal Court. The Making of the Rome Statute (The Hague/London/Boston: Kluwer Law International, 1999), 262-270; in D.L. Shelton, 'Reparations for Victims of International Crimes', in D.L. Shelton (ed.), International Crimes, Peace and Human Rights: The Role of the International Criminal Court (Ardsley: Transnational Publishers, 2000), 137-148.

68 Muttukumaru, 'Reparations to Victims', supra note 67, at 267. 
allowing a state to hide behind its organs), ${ }^{69}$ unless a compensation programme is provided for them.

In conclusion, at least in these 'residual' cases, Article 3 Hague Convention IV and Article 91, Protocol I might be construed in accordance with the principle whereby treaty rules must be 'interpreted and applied within the framework of the entire legal system prevailing at the time of the interpretation', as the International Court of Justice authoritatively put it in its Advisory Opinion in Namibia. ${ }^{70}$ Accordingly, those rules could be interpreted as granting to individuals a right to compensation in all those cases where compensation is not provided through interstate channels.

\section{Concluding Remarks}

The Italian Supreme Court's order must be appraised against the background of the traditional unwillingness of states to accept the notion of their liability towards individuals. Therefore, in addition to being open to the criticisms set out above, it may also be faulted because the judges did not take into account significant developments currently occurring in the international community. Marković would have indeed been an ideal case for an interpretation of Article 91, Protocol I more attuned to respect for the rights of individuals.

Considering the political situation developed in the aftermath of the NATO bombing campaign of 1999, it seems highly unlikely, if not impossible, that the FRY will exercise diplomatic protection to claim compensation for damages caused to its nationals by NATO forces. ${ }^{71}$ Nor does the conclusion of a compensation agreement

69 The right to seek compensation directly from the State responsible is all the more necessary in the case of large-scale military operations - especially air bombing - where the victims do not get to know the identity of the offender.

70 ICJ, Reports (1971), para. 53, at 31. Also the judges of the ECHR held, several times, that a treaty is a living instrument and must be interpreted in the light of the current international context. See, for instance, Loizidou v. Turkey, Judgment (Preliminary Objections), 23 March 1995, para.71; Selmouni v. France, Judgment (Merits and Just Satisfaction), 28 July 1999, para. 101.

71 Significantly, for instance, when the question of compensation for civilian casualties was raised during a debate at the House of Lords in July 1999 (following the NATO intervention), the British government denied any responsibility. It is worth reporting an excerpt of the debate: 'Baroness Turner of Camden asked Her Majesty's Government: "What arrangements are being made to ensure that civilian victims of NATO bombing in Kosovo, whether Albanian or Serbian, receive adequate compensation for injuries sustained?" Baroness Symons of Vernham Dean: "My Lords, our Armed Forces complied strictly with the laws of armed conflict, and in particular with the Geneva conventions and the first additional protocol to the conventions. Of course we regret any civilian casualties. Questions of possible compensation could arise only if unlawful action had been taken. We are satisfied that our action was lawful." Baroness Turner of Camden: "My Lords, I thank the Minister for that response. However, she will not be surprised that I find it somewhat disappointing. She said yet again that accidents happen in the shape of injuries and deaths to the civilian population. That being so, there seems to me to be an obligation upon all of us who gave support to this action - I believe that that represents a majority of the people in this country to accept some responsibility for the injuries and deaths caused to innocent people. Therefore will the Minister be good enough to think again in respect of her response to my Question?” Baroness Symons of Vernham Dean: "My Lords, I know that my noble friend is motivated by the best humanitarian principles. 
between NATO members and the FRY seem feasible. Unfortunately, this situation entirely matches the deplorable practice whereby only the vanquished countries eventually bear responsibility for the consequences of a conflict. Against this background, the interpretation of Article 91, Protocol I suggested above would have offered to the applicants in Marković the only possible way to obtain payment of damages.

More generally, given the significant developments referred to above, it must be hoped that national courts as well as states will gradually come to accept the aforementioned interpretation of the rule on states' liability for damages to individuals resulting from violations of humanitarian law, whereby such a rule grants them the right to an effective judicial remedy - at least in 'residual' cases. Such interpretation would indeed contribute to filling the gap existing at present between the international criminal system for remedying grave humanitarian law violations (war crimes) and the system for implementing states' responsibility for the same class of violations. It is utterly inconsistent to provide that victims may claim damages only from the state official found guilty of the crime, whereas it is left to the discretion of the victims' national state to ask for reparation, on their behalf, from the offender's national state. ${ }^{72}$ Acceptance of the above interpretation might also contribute to the gradual emergence of a customary rule laying down an obligation for states to compensate individuals for damages resulting from violations of humanitarian law.

However, there cannot be a question of compensation. That would arise only if unlawful action had been taken. NATO forces were very careful in their choice of targets. Of course anything that went wrong because of human error is very much to be regretted. But the fact remains that we are convinced that our action was lawful. We are convinced of the legality of our targeting and that our Armed Forces complied very strictly with the laws of armed conflict. In that case, I am afraid that there cannot be a question of compensation on this issue."' Lords Hansard, 26 July 1999, columns 1286-1287.

72 Ronzitti suggests this as the appropriate solution: 'Se la violazione della norma di diritto internazionale bellico comporta la commissione di un crimine di guerra, la vittima avrà il diritto di chiedere il risarcimento del danno. Ma per soddisfare tale pretesa, si dovrà convenire in giudizio l'individuo che ha commesso il crimine. In altri termini, qualora sia stato commesso un crimine di guerra, sussisterà una responsabilità internazionale dello stato, cui l'individuo organo appartiene, ed una responsabilità "personale" dell'individuo che ha commesso il crimine. La prima sarà fatta valere dallo Stato, cui la vittima appartiene, sul piano internazionale, la seconda, invece, dalla vittima nei confronti dell'individuo-organo', see Ronzitti, supra note 4 , at 687. 